\title{
Risk of Zoonoses among Livestock Farmers in Nepal
}

\author{
Kosh Bilash Bagale' (PhD Scholar) \\ Ramesh Adhikari², PhD.
}

\begin{abstract}
In Nepal most of the people are engaged in agriculture and livestock farming but having low knowledge and poor practices are making them prone to zoonoses threats. The aim of this study is to identify the risk of common zoonoses and existing knowledge, practices among livestock farmer in Nepal and all over the world. The study was conducted based on literature review. Literature search from Google Scholar, PubMed and Hinari databases was used for the study. The study shows that farmers have low knowledge and risky practices related to zoonoses. Sixty-five percent $(n=40)$ of pork handlers were not following safety. Thirty six percent cattle farmers used to dispose placenta, $39.65 \%$ of them aborted foetus. Similarly, $23.25 \%$ farmers gave intra uterine medication with bare hands and $30 \%$ were sleeping in animal shed $(n=250)$. African and South East Asian countries are facing more burden of zoonoses. Due to global warming and climate change, different zoonoses are emerging and re-emerging presentation in the world. Different research findings suggest that "One Health Approach" might help to fight against the zoonoses all over the world.
\end{abstract}

Key words: Endemic, emerging zoonoses, livestock, outbreak, zoonoses.

\section{Introduction}

Livestock is a part of human life, either single family, small society or a developed country started their successful journey from a small chicken, calf or short farm. During the civilization animal occupy a special role in human society. Without the proper care this relationship may lead to a serious public health risk with huge economic consequences. There are growing concern about disease that human can acquire from animals. Taylor, Latham, and Woolhouse (200I) reported that $61 \%$ of all human pathogens are zoonotic.

Nepal is a pluralistic society with diverse ethnic, linguistic and socio-economic characteristics. Most of the farmers cultivate mixed crops as well as rear livestock according to the needs of their families and follow traditional practices which may increase risk for zoonoses. Nowadays, paradigm has been shifted. Due to the globalization, industrialization, and commercialization, people are shifting to commercial farming. But this may raise a question whether farmers are competent enough with relevant training and education. Illiteracy, poverty, traditional practices might have strong association with zoonotic diseases prevalence in countries like Nepal.

According to World Health Organization (WHO), 'Zoonoses are those diseases and infections which are naturally transmitted between vertebrate animals and human'. There are many

\footnotetext{
${ }^{1}$ Corresponding Author: Kosh Bilash Bagale, PhD Scholar, Graduate School of Education, TU, Kirtipur, Kathmandu, E-mail: koshbagaleI23@gmail.com

2 PhD., Professor and Head, Geography and Population Department, Mahendra Ratna Campus, Tribhuvan University, Kathmandu
} 
examples of zoonotic diseases prevalent in the world. The three recent worldwide viral outbreaks, namely SARS (Severe Acute Respiratory syndromes), the bird flu ( $\mathrm{H} 5 \mathrm{NI})$ and the swine flu (HINI) are all examples of infections passed from animals to humans. Even the HIV virus was transferred from chimpanzee to humans in the last century (Basnyat, 2013). The Asian country India has the highest prevalence of rabies followed by Africa (WHO, 2018). Brucellosis, Taenia cysticercosis and Swine flu also have high prevalence in India. In 2009 Swine flu was pandemic all over the world emerging from Mexico. (Kang, Gunaseelan, \&Abbas, 20I4; Adhikari et al, 2009; Joshi et al 2018). In Nigeria 3044 human deaths occurred due to brucellosis and 300 thousand humans were affected by bovine tuberculosis in 2016 (FAO, 2018). Rabies, taenia cysticercosis, brucellosis, toxoplasmosis swine flu, avian influenza, dengue fever are the major zoonotic diseases with endemic potential in Nepal (DoHS, 2072/073).

People who are close to animal and have a poor knowledge and practices are more susceptible to zoonoses disease. Livestock farmers, veterinarian, para- veterinarian are closer to animal due to their profession. Similarly, children who are close to their pets are also at risk for zoonoses. People living around the wildlife human interface region such as buffer zones of protected area are also in greater zoonoses risk (Niroula, 2016).

Due to the lack of studies on the incidence and prevalence of zoonotic disease, a clear picture about them cannot be drawn in Nepal. However, a few studies that have been conducted shows that many common zoonotic diseases are present at an alarming proportion. On the other hand, in country like Nepal, ethnicity, culture and traditional practices are making us more susceptible to the zoonotic disease (Niroula, 2016). Drinking raw yak blood on some occasions in the Himalayans regions, drinking cow urine in some Hindu religious ceremonies etc. are some examples of them.

This paper tries to explore the knowledge and practice related to zoonosis on livestock farmers and identify the impacts of different socio- demographic variables in the field of livestock farming in Nepal. Study was conducted based on literature review. To cover the objectives, this paper tries to answer some research questions like, What are the practices of livestock farmers on safety precaution during exposure with animals? What is the gap between the knowledge and current practices related to zoonosis prevention in the community?

\section{Methods}

Literature review was conducted across multiple data- bases including Google scholar, PubMed, BioMed and Hinari databases for study published in English using the word search terms related to livestock farmers and zoonoses, like knowledge, practice, emerging, reemerging, risk, precaution, culture and livestock etc. Some articles and documents published by Department of Health Service were also reviewed. Study title and abstracts were searched with full article obtained and re-evaluated for inclusion and exclusion under the following criteria:

Inclusion criteria: Article related to zoonoses and livestock farmers, zoonoses related to interventional studies, knowledge and practice in zoonoses field and zoonoses prevalence related studies. 
Exclusion criteria: Articles other than English language, livestock with commercial aspects and articles which are not relevant to zoonotic disease and case report. Based on above criteria, a total 123 abstract were reviewed, with 57 full text review and 18 papers included in the final analysis.

Total titles and abstracts $\mathrm{N}=123$

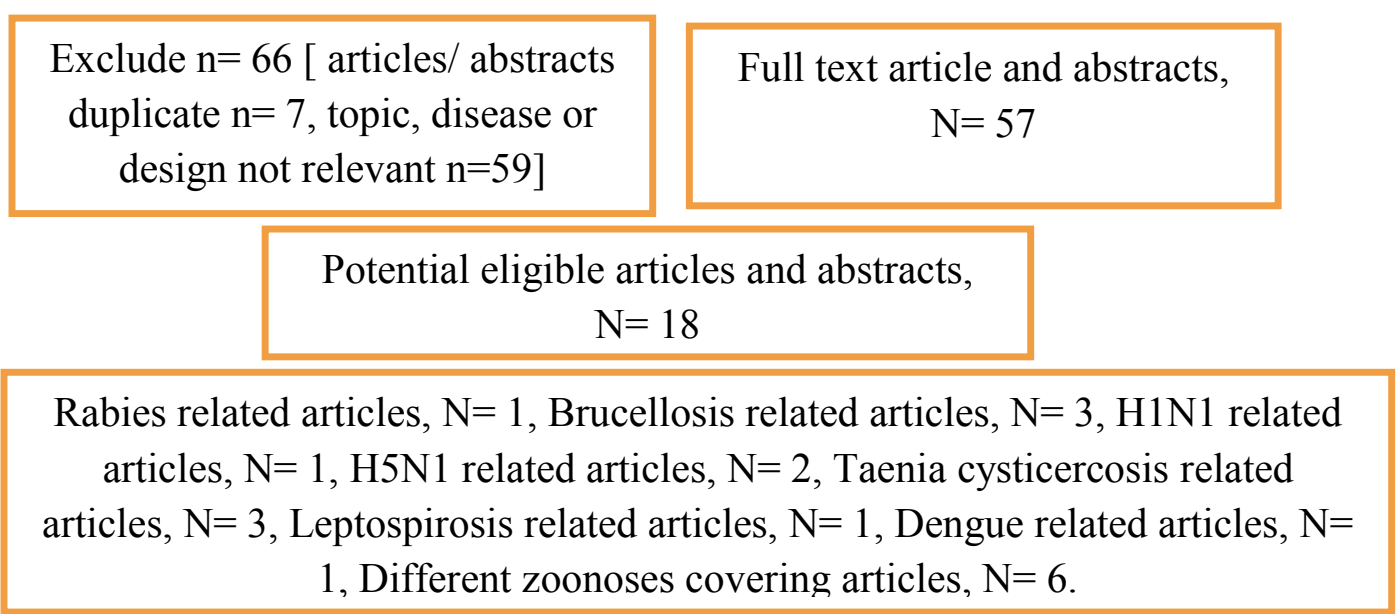

Figure I. Identification and selection of eligible studies

Ethical Consideration: It is just a review article and available relevant literature are obtained from multiple data- bases including Google scholar, PubMed, BioMed, Hinari etc.

Global situation of zoonotic disease prevalence based on literature review:

Rabies: Rabies is an acute highly fatal viral disease of central nervous system caused by Lyssa virus type I. It is primarily a zoonotic disease of the warm-blooded animal, particularly carnivorous such as dogs, and wolves. Some countries have achieved rabies free status by virus campaigns of elimination. The virus is transmitted through wounded or abraded skin or mucous membrane when the infected animal licks or bites another animal or man.

Globally annual 55,000 people died due to the rabies and $45 \%$ global burden in SEAR. However, it is a vaccine preventable disease (WHO, 2018). Human rabies is present in 150 countries and territories, except for Antarctica. The ratio is highest in Asia (India) and this is closely followed by Africa. However, estimates of burden have always been uncertain due to absence of reliable data. Dog is the main source of human rabies deaths, contributing up to $90 \%$ of all rabies deaths. Rabies elimination /eradication countries like Australia, Japan, Hongkong, Maldives, UK etc eradicated through the dog licensing, euthanasia of stray dogs and mass vaccination. About 1.5 billion people are at potential risk of rabies infection and 4 million people receive ARV (Pant, 2012). Rabies is endemic in Nepal about 1500 people die every year due to rabies (WHO, 2018). To control the rabies ARV is available in 54 hospital regularly for post exposure prophylaxis (PEP). Government of Nepal expands US\$ 1.5 million/ year to buy ARV (EDCD, 2016). 
Brucellosis: Brucellosis is the most common bacterial infection caused by a group of bacteria from the genus brucella that spreads from animal to human, most often through the unpasteurized milk, cheese and other dairy products. Sometimes, it spreads from direct contact with infected animals and their discharge. In the initial stage brucellosis can be hard to identify because symptoms are much similar like other flu.

According to World Organization for Animal Health, Brucellosis is the second most important zoonotic disease in the world after rabies (Acharya, Niroula, \& Kaphle,2017). Annually about 200 per million individuals die from human brucellosis. In India, approximately $80 \%$ people live with in close contact to domestic and wild animals which create critical risk of zoonotic disease transmission such as brucellosis (Kang, Gunaseelan, \& Abbas, 2014). Brucellosis has been reported endemic in Nepal. Most of the livestock farmers have no knowledge about human brucellosis which may outbreak anytime and anywhere. In Nepal the first human case was reported in 1979 in Pokhara (Acharya et al., 2017). Similarly, in 2015 brucellosis outbreak in Dhunkarka VDC, Kavre with seven human infection (Rupblica, Sep-7, 2015). Health care practitioners should be aware of possibilities of this zoonotic infection and include brucellosis as a differential diagnosis in patients with nonspecific symptoms and unexplained prolonged fever.

Swine Flu (HINI): Swine flu, caused by HINI virus, is a relatively new strain of an influenza virus the symptoms of which are similar to the regular flu. It is newly emerged zoonotic disease which is dangerous for human because our immune system has had no change to prepare the defensive measures which can protect us from normal flu. Some people are more at risk of catching swine flu like, people aged over 65, children below five, people with chronic disease, pregnant women and anyone with compromised immune system (WHO, 20I0).

Swine flu pandemic outbreak in 2009 began from Mexico reported with 25,214 cases and 217 cases died, then spread all over the world. At least 74 countries reported approximately 30,000 confirmed laboratory cases. In 2010 February world-wide, more than 213 countries reported laboratory confirmed cases with at least 16,455 deaths. Globally, afflicted at least 394, I33 people in Asia with 2,137 confirmed deaths: there were I,035 deaths confirmed in India, 737 in China, 4I5 in Turkey, 192 in Thailand, and 170 deaths in South Korea. Among the Asian countries, South Korea had the most confirmed cases, followed by China, Hong Kong, and Thailand and $172 \mathrm{HINI}$ case was reported with 2 deaths in Nepal in 2009 (Adhikari et al., 2009).Very recent re-emerging outbreaks in Sep 2018 about 2100 people suffered by Swine flu and Hongkong flu with 4 death in Saptari district in Nepal (Sharma, 2018).

Avian Influenza $(\mathrm{H} 5 \mathrm{NI})$ : Avian influenza $(\mathrm{H} 5 \mathrm{NI})$ refers to the disease caused by avian (bird) influenza type $A$ viruses. $\mathrm{H} 5 \mathrm{NI}$ virus naturally occurs among wild aquatic birds worldwide and can infect domestic poultry and other birds and animal species. Avian flu does not normally infect humans, but it can happen when virus is in the air and a person breathes it in. Since the avian influenza $A(\mathrm{H} 5 \mathrm{NI})$ virus had re-emerged in 2003 and 2004, after the first report of infection in humans in 1997 during a poultry outbreak in Hong Kong (WHO, 2013).

In SEAR, the total number of human avian influenza $A$ cases reported since the beginning of 2004 till 2013 is 228 with 181 fatalities. In 2013 alone, there were 4 cases, with 4 fatalities, of 
human influenza A H5NI reported to WHO from Bangladesh and Indonesia (WHO, 20I3). In Nepal, at 2065 Avian influenza was first time seen in Hetauda. Till now it was seen 106 times in Nepal and 36 times in Kathmandu (Aryal, 2013).

Taenia Cysticercosis: Taeniasis is an intestinal infection, adult tapeworms caused by ingestion of infected pork. Cysticercosis is infection with larvae of T. solium. Adult worms may cause mild Gl discomfort or passage of a motile segment in the stool. It is usually asymptomatic unless larvae enter the brain, resulting in neurocysticercosis, which can cause seizures and various other neurologic signs. Three human Taenia species, T. solium, $T$. saginata, and $T$. asiatica, are endemic in rural regions of Asia and several patients report from in Asian countries indicate the wide prevalence of taenia solium cysticercosis. Cysticercosis is the causes of epilepsy in up to $50 \%$ of India patients presenting with partial seizures. It is also major causes of epilepsy in Indonesia, Vietnam and Nepal (Joshi et al., 2018).

Dengue Fever: Dengue is also called a break-bone fever. It is a vector born viral disease caused by Dengue Virus (DENV). Aedes aegypti mosquitoes are the vector of dengue fever. They are usually found in urban and suburban areas as they like to breed in man-made containers like drains, flowerpots. Before 1970 only 9 countries had experienced severe dengue epidemics, but now more than 100 countries have epidemic. The incidence of dengue has been growing dramatically all over the world in recent decades consequently affecting health of children in some Asian and Latin American countries. The prevalence of dengue estimates that 3.9 billion people in 128 countries are at risk of infection with dengue virus. Africa and SEA are most seriously affected by dengue fever (WHO, 20I8). Climate change, poor WASH practices is the most challenging aspect to control zoonosis in Nepal. DoHS state that in F/Y 2072/073 total number of dengue case reported from 12 districts were 302. Initially most cases had travelled to the neighbouring country (India), although lately indigenous cases are also being reported.

\section{Results}

Rabies, brucellosis, swine flu, avian influenza, taenia cysticercosis, dengue fever, are common zoonotic disease with endemic potential in developing countries like Nepal. In this situation if farmers have low knowledge and poor practices, they are more susceptible to zoonoses due to their closeness with livestock. The following is a brief scenario of some zoonotic disease and livestock farmers knowledge and practices based on selective reviewed article:

\begin{tabular}{|c|c|c|c|}
\hline Title & Purpose of study & Methods & Results / Findings \\
\hline $\begin{array}{l}\text { Rabies Control } \\
\text { Strategy in SAARC } \\
\text { Member Countries } \\
\text { (Pant, 20I2). }\end{array}$ & $\begin{array}{l}\text { Rabies control } \\
\text { strategy, program, } \\
\text { challenges and } \\
\text { constraints in SAARC } \\
\text { countries. }\end{array}$ & $\begin{array}{l}\text { Strategic } \\
\text { review and } \\
\text { analysis of } \\
\text { hospital data. }\end{array}$ & $\begin{array}{l}\text {-Majority of human rabies case } \\
(90 \%) \text { transmitted from domestic } \\
\text { dogs. } \\
-1.5 \text { billion people are at potential risk } \\
\text { of rabies infection. }\end{array}$ \\
\hline $\begin{array}{l}\text { Review of Brucellosis } \\
\text { in Nepal } \\
\text { (Acharya et al., } \\
\text { 2017). }\end{array}$ & $\begin{array}{l}\text { Evaluate the current } \\
\text { status of human } \\
\text { brucellosis in } \\
\text { developing country } \\
\text { like Nepal. }\end{array}$ & $\begin{array}{l}\text { systematic } \\
\text { review }\end{array}$ & $\begin{array}{l}\text {-Incidence of brucellosis has been } \\
\text { increasing threats in Asia. } \\
\text {-for brucellosis eradication needs } \\
\text { funds \& collaboration with veterinary, } \\
\text { public health \& political as well. }\end{array}$ \\
\hline $\begin{array}{l}\text { Epidemiological } \\
\text { Modelling of Bovine } \\
\text { Brucellosis in India }\end{array}$ & $\begin{array}{l}\text {-To develop an } \\
\text { epidemiological } \\
\text { model of brucellosis }\end{array}$ & $\begin{array}{l}\text { Mathematical } \\
\text { modelling of } \\
\text { infectious }\end{array}$ & $\begin{array}{l}\text { Annually I- } 200 \text { per million individuals } \\
\text { died from human brucellosis. In India } \\
\text { approximately } 80 \% \text { people live with in }\end{array}$ \\
\hline
\end{tabular}




\begin{tabular}{|c|c|c|}
\hline (Kang et al., 20l4). & $\begin{array}{l}\text { transmission. } \\
\text {-To estimate the } \\
\text { impact of different } \\
\text { prevention and } \\
\text { control strategy. }\end{array}$ & $\begin{array}{l}\text { disease } \\
\text { dynamics } \\
\text { designs and } \\
\text { test. }\end{array}$ \\
\hline $\begin{array}{l}\text { KAP relating to } \\
\text { brucellosis in small } \\
\text { holder dairy farmers. } \\
\text { Pakistan } \\
\text { (Arif et al., 2017). }\end{array}$ & $\begin{array}{l}\text { To find out KAP } \\
\text { towards brucellosis } \\
\text { among small holder } \\
\text { dairy farmers }\end{array}$ & $\begin{array}{l}\text { Cross } \\
\text { sectional } \\
\text { survey study }\end{array}$ \\
\hline $\begin{array}{l}\text { Outbreak of } \\
\text { pandemic influenza A, } \\
\text { HINI } 2009 \text { in Nepal } \\
\text { (Adhikari et al., }\end{array}$ & $\begin{array}{l}\text { Find out the actual } \\
\text { outbreak's situation } \\
\text { and HINI severity in } \\
\text { Nepal }\end{array}$ & $\begin{array}{l}\text { Laboratory } \\
\text { based, cross- } \\
\text { sectional } \\
\text { study }\end{array}$ \\
\hline
\end{tabular}
2009).

\author{
$\mathrm{KAP}$ related to $\mathrm{Al}$ \\ among poultry \\ workers of \\ Bangladesh \\ (Hossan, Eusufzai, Elii, \\ \& Jamayef, 20 I5).
}

\section{Taeniasis /}

cysticercosis situation in Nepal (Joshi et al., 2018).

\section{To find out KAP of poultry farmers in Bangladesh.}

To analyse the prevalence of Taeniasis in Nepal.

\section{Cross sectional random survey}

Hospital based study close contact to domestic and wild animal which create critical risk of zoonotic disease transmission such as brucellosis.

- Overall KAP are not satisfactory. - 74\% respondents had not idea about human brucellosis. $97 \%$ respondents did not know mode of transmission about brucellosis. $60 \%$ consume raw milk.

- Half of the family have a close contact with animal and share the same housing.

Out of 609 collected samples, 302 (49.6\%) were Universal Influenza A positive. Among the influenza $A$ positive samples, I72(28.3\%) were positive for Pandemic influenza $\mathrm{A} / \mathrm{HINI}$ and I 30 (2I.3\%) were Seasonal influenza $A$.

Most of the pandemic cases (53\%) were found among young people with $\leq 20$ years. Case Fatality Ratio for Pandemic influenza A/HINI in Nepal was $1.74 \%$.

- Only 34\% respondents said that they were washing hands after poultry care.

- 32\% used personal protective equipment during the poultry care can prevent Avian influenza. - Most of the respondents informed Rapid Response Team (RRT) for management of sick or dead poultry. - Post-mortem surveys of pigs at slaughter establishments in Kathmandu and Dharan showed 14\% (34/250) of pigs positive for cysticercosis.

- A human helminthological survey in Syangja Nepal indicated a very high prevalence of taeniasis, with $43 \%$ positive (77//80), while in Tanahun I8\% were positive (28/I52).

- Prevalence of dengue estimates that 3.9 billion people in 128 countries are at risk of infection with dengue virus. - Dengue case was increased from 2.2 million in 2010 to 3.2 million in 2015 in member countries of $\mathrm{WHO}$. 
Annual report of

DoHS 2072/073

\section{Assessment of pork} handlers' knowledge and hygienic status of pig meat shops of Chitwan ...

(Ghimire et al., 2013).

Evaluation of farmers KAP about zoonotic disease in Turkey (Cakmur et al., 20I5). Zoonotic disease, human health, \& farm animal welfare (WSPA, 2009).
Awareness, knowledge \& risk of zoonotic disease among livestock farmers in Punjab (Hundal et al., 2016).
To find out

knowledge and

hygienic practices of pig meat shops
Cross

sectional study
To determine KAP of Turkey's livestock farmers.

WSPA reports related to zoonoses and human health.
- Africa and SEA are most seriously affected by dengue.

- Dengue positive case was decline dramatically $(785,302$ \& 134 in 070/7I, 07I/72 \& 072/073 respectively) but case was distributed in increasing trend $(12,15 \& 26)$ districts. It was high prevalence in terai among the farming community.

- $\quad 65 \%(n=40)$ pork handlers were aware about pork borne disease but none of them had heard about campylobacteriosis.

- Only 30\% of the pork handlers wore apron regularly. None of them wore gloves and masks and $40 \%$ even did not wash hands regularly.

- The hygienic practices like sanitation of equipment's and regular washing of hands were significantly associated $(p<0.05)$ with level of education.

- There were risky practices among farmers compared to middle level knowledge among educated people about zoonotic disease on Turkey. - Industrialization of livestock led to zoonotic risk.

- The risk of new strains of influenza that can infect humans is of serious concern, now and in the future.

-Farm animal numbers have risen rapidly, and large-scale concentration of poultry and pigs. This increases the risk of new strains of influenza viruses emerging and spreading.

Investigate risk and Purposive assess knowledge and study awareness level of zoonotic diseases among livestock farmers.
-Respondents not only disposed off the infected placenta $35.6 \%(n=250)$ aborted foetus (39.6\%), or feces (56.4\%) from a diarrheic animal but also gave intrauterine medication (23.2\%) bare-hands and $30 \%$ were sleeping in animal shed.

- About 84.8\%, 46.0\%, 32.8\%, 4.61\%, and $92.4 \%$ of livestock farmers were aware of zoonotic nature of rabies, brucellosis, tuberculosis, anthrax, and bird flu, respectively.

- The transmission of rabies through dog bite $(98.4 \%)$, need of post- 


\begin{tabular}{|c|c|c|c|}
\hline $\begin{array}{l}\text { Assessment of } \\
\text { community KAP on } \\
\text { milk borne zoonoses } \\
\text { disease in Ethiopia } \\
\text { (Delelegn\&Girma, } \\
\text { 2018). }\end{array}$ & $\begin{array}{l}\text { Assess KAP and } \\
\text { determine the effect } \\
\text { of demographic } \\
\text { character towards } \\
\text { milk bornedisease }\end{array}$ & $\begin{array}{l}\text { Cross } \\
\text { sectional } \\
\text { random } \\
\text { sampling. }\end{array}$ & $\begin{array}{l}\text {-Most of farmer did not get a training } \\
\text { on related field. } \\
-64 \% \text { illiterate population did not } \\
\text { know preventive methods of milk } \\
\text { borne disease. } 57 \% \text { did not check milk } \\
\text { for its quality. }\end{array}$ \\
\hline $\begin{array}{l}\text { Leptospirosis: An } \\
\text { emerging infectious } \\
\text { disease in Nepal } \\
\text { (Bhattachan et al., } \\
\text { 20l6). }\end{array}$ & $\begin{array}{l}\text { To determine the } \\
\text { prevalence of } \\
\text { Leptospira spp in } \\
\text { Japanese Encephalitis } \\
\text { negative cases. }\end{array}$ & $\begin{array}{l}\text { Hospital based } \\
\text { study using } \\
\text { ELIZA method }\end{array}$ & $\begin{array}{l}\text {-Among } 993 \text { JE negative case, } \\
\text { positivity rate of leptospira SPP was } \\
\text { reported } 41.8 \%(416 / 993) \text {. }\end{array}$ \\
\hline $\begin{array}{l}\text { National livestock } \\
\text { policy of Nepal: } \\
\text { Needs and } \\
\text { Opportunities } \\
\text { (Pradhanang et al., } \\
2015) \text {. }\end{array}$ & & - policy review & $\begin{array}{l}\text { National livestock policy mainly } \\
\text { focused on economic development, } \\
\text { equity, poverty alleviation, gender } \\
\text { mainstreaming, inclusion of } \\
\text { marginalized and underprivileged } \\
\text { communities, and climate } \\
\text { vulnerability. }\end{array}$ \\
\hline $\begin{array}{l}\text { Neglected zoonosis } \\
\text { situation in Nepal } \\
\text { (Jha, 20I5). }\end{array}$ & Reports & - & $\begin{array}{l}\text { - National zoonotic diseases control } \\
\text { programme is lacking. } \\
\text { - Surveillance plan and laboratory } \\
\text { diagnostic capacity for priority } \\
\text { zoonotic diseases is not adequate. } \\
\text { - There are high chances of disease } \\
\text { transmission in weekly livestock } \\
\text { market. } \\
\text { - Poor linkage with animal health and } \\
\text { public health. } \\
\text { - One health approach is very weak in } \\
\text { Nepal. }\end{array}$ \\
\hline
\end{tabular}

\section{Discussion}

Livestock is relatively closer for farmers mainly in developing countries, because they act as a critical source of survival. In Nepal, $66 \%$ of the population are engaged in agriculture, but it is evident that $25 \%$ people are living under the poverty line (CBS, 20I2). This fact reflects that, most of the farmers in Nepal followed the traditional farming with various professional hazards. Some literature which were reviewed in this article reflect that, not only Nepali farmers but farmers in many others developing countries also followed the risky practices in this field, which causes huge economic and human losses.

Ghimire et al. (2013) mention the low knowledge and risky practices related to zoonoses among the pork handlers in Chitwan Nepal. Hossan et al. (2015) showed the poor practices 
among poultry farmers in Bangladesh. Delelegn \& Girma, (2018) found that, most of farmer did not get a training on related field. Sixty four percent illiterate population did not know preventive methods of milk borne disease, $57 \%$ did not check milk for its quality in Ethiopia. Arif et al. (2017) found that overall knowledge attitude and practices (KAP) are not satisfactory among livestock farmers related to brucellosis in Pakistan. About half million of estimated new cases of brucellosis was reported throughout the world with high prevalence in Africa and SEAR. But due to illiteracy and poor knowledge, farmers not only disposed off the infected placenta (35.6\%), aborted foetus (39.6\%), or feces $(56.4 \%)$ from a diarrheic animal but also gave intrauterine medication (23.2\%) with bare hands in Punjab (Hundal et al., 2016).

Tape worm infestation is common not only in pigs consuming society but is also caused by uncooked (pork) meat and unhygienic vegetables. It is responsible for neuro cysticercosis which is difficult to diagnose. Epilepsy cases in Nepal are increasing up to 7.3/1000 population, and 50 percent of the case are due to neuro cysticercosis (Joshi, Bista, Ito, \& Yamasaki, 2007). Low socio-economic status, free range of pig rearing system, food preparation and consuming habits are responsible for worsening the situation.

Due to impact of global warming and climate change, many emerging zoonoses appear in the world which increase the zoonoses burden and public health threats. In the same time industrialization of livestock led to zoonoses risk (WSPA, 2009) specially in new strain of influenza virus. Due to the impact of climate change, Aedes aegypti which is the vector of dengue is surviving in hilly and mountainous region which is a burden on public health in developing country like Nepal. In global scenario, dengue case increased from 2.2 million in 2010 to 3.2 million in 2015 in member countries of WHO. However, in Nepal dengue cases were declining but still the disease is prevalent in hilly and mountainous districts, which may also be the impact of climate change and global warming.

Swine flu (HINI) and Avian influenza (HIN5) are viral zoonotic diseases which seem like normal flu but create severe public health threat as they are highly infectious. They can spread in epidemic and pandemic nature with huge economic and human loss if required measures are not carried out in time. Very simple preventive measures like hand washing and mask wearing practices support to protect flu like these.

Globalization, industrialization and commercialization led to huge number of people having adopted the livestock profession with sound income. But this raises the question whether they are competent with well training and sound knowledge of fundamental requirement for zoonoses protection to livestock farmers. Delelegn \& Girma (20I8) show that people adopted farming profession without any training and do not have knowledge for zoonoses prevention.

We generally assume that if people have good knowledge, they will use hygienic practices. But surprisingly, receiving the higher education only significantly upgrades their knowledge, but level of attitude and practices did not change based on that knowledge. Majority of the population $(80.1 \%)$ knew that sick animal's corpse should be buried deep, but the ratio of these practices was identified only $22.5 \%$. (Cakmur et al., 20I5). So, based on above evidence there was a huge gap between knowledge and practices among the farmers in Turkey. This 
evidence raised the challenges in the field of health education and health promotion all over the world.

Reports shows that, there were single or multiple zoonoses threats associated with the traditional management and unhygienic practices in most of the developing countries. But due to illiteracy and ignorance, people are unaware that livestock may be source of zoonotic disease and some of them are amplifier host in different lethal pathogens and some play a role for transformation as asymptomatic carrier. Our cultural and traditional values, poverty and illiteracy make us closer with livestock without any safety and precaution. Nowadays in the field of zoonoses, 'One Health' concept is taking effect which acts as a collaborative, multisectoral, and transdisciplinary approach working at the local, regional, national, and global levels with the goal of achieving optimal health outcomes recognizing the interconnection between people, animals, plants, and their shared environment.

\section{Conclusion}

In conclusion, many developed countries have eliminated and eradicated different fatal zoonoses while, on the other hand, people in developing countries are dying even of vaccine preventable diseases. In the global context, African and South East Asian countries are facing more burden of zoonoses. Based on reviewed literature, livestock farmers had low knowledge and poor practices related to zoonoses in many developing countries including Nepal, which is a threat for zoonoses outbreaks anytime and anywhere. So, we need to make intervention plan without any delay based on One Health concept. Health education in school curriculum, awareness activities, prophylaxis treatment and vaccination programme are some suggestive preventive aspects to control zoonotic disease with the collaboration of all stakeholders under the same umbrella based on one health concept.

\section{References}

Acharya, K. P., Niroula, N., \& Kaphle, K. (2017). Review of brucellosis in Nepal. Epidemiology and Health. Published online 2017 Apr 24. doi: 10.4I78/epih.e20I70I8.

Adhikari, B. R., Shakya, G., Upadhyay, B.P., KC, K. P., Shrestha, S. D., \& Dhungana, G. R. (2009). Outbreak of Pandemic Influenza A/HINI 2009 in Nepal. Published online 20II Mar 23. doi: $10.1186 / 1743-422 X-8-133$

Arif, S., Thomson, P. C., Jover, M. H., McGill, D. M., Warriach, H. M., \& Heller, J. (2017). "Knowledge, attitude and practices relating to Brucellosis in small holder dairy farmers in two provinces in Pakistan". Retrieved from http:// doi: 10.137//journal.pone.0173365. eCollection 2017.

Anonymous, (2015). Kavre outbreak caused by brucellosis. Republica Online Paper, Retrieved from http://admin.myrepublica.com/society/story/27732/kavre-outbreak-caused-bybrucellosis.html

Aryal, R. (20/3). Havoc of bird flu in poultry farm industry of Nepal. Retrieved from https://rameshtalks.wordpress.com/tag/bird-flu-in-nepal/

Basnyat. (20I3). From animals to human. Published in Magazine Issue: Vol: 07 No. -I June I42013 (Jestha 3I, 2070). 
Bhattachan, B., Bhattachan, A., Sherchan, JB., Dhoubhadel, BG., \& Sherchan JB. (2016). Leptospirosis: An Emerging Infectious Disease in Nepal. Journal of Institute of Medicine,Aug.Dec., 2016, 38:2-3 PP 63-68

Cakmur, H., Akoglu, L., Kahraman,E., \&Atasever, M. (20I5). Evaluation of Farmers' KnowledgeAttitude-Practice About Zoonotic Diseases in Kars, Turkey.doi: 10.5505/kjms.2015.83436

CBS (2012). Central Bureau of Statics. National Population and and Housing Census $201 \mathrm{I}$ (National Report). Volume 0I.

Delelegn, M., \& Girma Y. (2018). Assessment of community knowledge, attitude and practice on milk borne zoonoses disease in Debre- Birhan town, north Shewa, Ethiopia. A Journal of Public Health and Epidemiology. doi: 10.5897/JPHE20 17.0983

DoHS (2072/73). Annual reports of Department of Health Services. Kathmandu, Teku: Minister of Health and Population, Department of Health Services.

EDCD (2016). Early Warning and Reporting System (EWARS), Guidelines Government of Nepal.Epidemiology and Disease Control Division, Kathmandu.

FAO (2018). Food and Agriculture Organization of United Nation. The Monetary Impact of Zoonotic Disease on Society Nigeria, Evidence from Four Zoonoses. Retrieved from: http://www.fao.org/3/i8968en/l8968EN.pdf

Ghimire, L., Dhakal, S., Pandeya, Y. R., Chaulagain, S., Mahato, B. R., Satyal, R.C., \& Singh, D.K., (20I3). Assessment of pork handlers' knowledge and hygienic status of pig meat shops of Chitwan district focusing campylobacteriosis risk factors. A research articles. Retrieved from doi.dx.org/l0.3/26/ijim.v2il.8004

Hossan, M.S., Eusufzai, S.Z., Elihi, M.M \& Jamayet, N. (20I5). knowledge, attitude and practices related to Avian Influenza among poultry workers of Bangladesh. Bangladesh Journal of Veterinary Medicine. doi: 10.3329/bjvm.v I4il.28819

Hundal, J.S., Singh, U., Singh. N., Kansal, S. K., \& Bhatti, J. S. (2016). Impact of Training on Knowledge of Goat Farmers in Punjab. Department of Veterinary and Animal Husbandry Extension Education, College of Veterinary Sciences GADVASU, Ludhiana- I4I 004, India.

Jha, V. C. (2015). Neglected zoonoses situation in Nepal. Retrieved from http://cdn.aphca.org/dmdocuments/Events/I5-I6_July-I5/Presentations/Day I/I3NZD\%20Nepal_Dr\%20Jha.pdf

Joshi, D.D., Maharjan, M., Jshnsen, MV., Willingham,A. L., Gaihr, Y., \&Sharma, M. (20/8).Taeniasis/cysticercosis situation in Nepal. Retrieved from https://idocslide.com/thephilosophy-of-money.html?utm_source=taeniasis-cysticercosis-situation-in-nepal

Joshi, D. D., Bista, P. R., Ito, A., and Yamasaki, H. (2007). Present Situation of Porcine Taeniasis and Human Cysticercosis in Nepal. Retrieved from http://www.tm.mahidol.ac.th/seameo/ 2007-38-suppl-I/38suppl I-I44.pdf

Kang, G. J., Gunaseelan, L.,\& Abbas, K. M.(20/4). Epidemiological Modeling of Bovine Brucellosis in India. Retrieved from https:/www.ncbi.nlm.nih.gov/pmc/articles/ PMC453729I/ 
Niroula, N. (2016). Risk of Zoonosis. Retrieved from Kathmandu Post July 29, 2016.

Pant, G. R. (20I2). Rabies Control Strategy in SAARC Member Countries. Retrieved from http://www.oie.int/doc/ged/DI2940.pdf

Pradhanang, U. B., Pradhanang, S. M., Sthapit, A., Krakauer, N.Y., Jha, A., \& and TarendraLakhankar, T. (2015). National Livestock Policy of Nepal: Needs and Opportunities. Retrieved from Online journal. Doi: doi: 10.3390/agriculture5010103

Sharma, D. (20I8). Difficult for Flu treatment without specialist doctor in Saptari. Published on Swasthya Khabar Patrica. Dated: September - 16, 2018.

Taylor, L. H., Latham, S. M., \& Woolhouse, M. E. (200I). Risk factors for human disease emergence. Retrieved from http:// Philos Trans R Soc Lond B Biol Sci. 200I Jul 29; 356(I4II): 983-989.doi: 10.1098/rstb.200I.0888

WHO (2010). Emergencies preparedness, response. Retrieved from// http://www.who.int/csr/ disease/swineflu/frequently_asked_questions/risk/en/

WHO (2013). Avian Influenza in the South-East Asia Region. Retrieved from http://www.searo.who.int/entity/emerging_diseases/topics/avian_influenza/en/

WHO (2018). Strategic Framework for Elimination of Human Rabies Transmitted by Dogs in Southeast Asian Region. Retrieved from https://apps.who.int/iris/ handle/I0665/205920

WHO (2018). Dengue and Severe Dengue. Retrieved from http://www.who.int/news$\mathrm{room} /$ fact-sheets/detail/dengue-and-severe-dengue

WSPA (2009). Zoonotic Diseases, Human Health and Farm Animal Welfare. Retrieved from https://www.ciwf.org.uk/media/3756/23/Zoonotic-diseases-human-health-and-farmanimal-welfare-16-page-report.pdf 